\title{
"The Jesuit mission proves we were here": The Case of Eighteenth-Century Jesuit Missions Aiding Twenty-First Century Tribal Recognition
}

\author{
Andrew R. Beaupré \\ Department of Anthropology and Arkansas Archeological Survey, \\ University of Arkansas, Fayetteville, AR, USA \\ abeaupre@uark.edu
}

\begin{abstract}
Records indicate that during the French colonial period, Jesuits established four mission congregations within the territory now known as Vermont. These missions were established to preach to both French colonists and Native converts on Isle La Motte, on the Missisquoi River in Swanton, at Fort Saint-Frédéric on Lake Champlain, and in the area known as the Koas on the Connecticut River. In the twentieth and twenty-first centuries, the Abenaki peoples of Vermont have had a long and difficult road to gain state and federal recognition. These descendant communities have invoked the existence of Jesuit missions to the Abenaki as proof of the current tribal governments' legitimacy. This is intriguing considering the blame for cultural destruction is often laid at the feet of Jesuit missionaries. This paper examines the relationship between historical and archaeological evidence of French Jesuits and the legal legitimization of the Abenaki of Vermont.
\end{abstract}

\section{Keywords}

Western Abenaki - Jesuit missions - archeology - Vermont - tribal recognition Cowasuck - Koasek - Cowass 


\section{Introduction}

"If the Koas village didn't exist, why did the Jesuits have a mission here? We have the maps, we have the documents. The Jesuit mission proves we were here. We know we existed because the Jesuits were here."1

The above is a paraphrased quote by Nathan Pero, the elected chief of the Koasek (Cowasuck) Traditional Band of the Sovereign Abenaki Nation. ${ }^{2}$ Chief Pero's exact words have been lost to time, due to a poor-quality digital recording in a cavernous meeting room. Regardless of his exact phrasing, Chief Pero spoke with great passion during an open meeting of the Vermont Commission of Native American Affairs, in fervent defense of his band's application for state recognition. ${ }^{3}$ One could not help but be moved by the passion with which Chief Pero spoke. To many in the academy and politics, the details of tribal recognition are but clauses marred by the abstruse technical vocabulary of legislative action. In this statement, Chief Pero was not merely applying for a local political designation, but indeed, testifying for what he saw as the right for his people to exist.

I was struck by Pero's use of Abenaki association with Catholic missionaries, and by the reliance on the historical ties between the proselytization of his people by French Jesuit missionaries and the fight for twenty-first century recognition of the Koasek Abenaki sovereign identity. This comment casts a positive light on the historical connections among multiple Native American and First Nations Peoples and French Catholic missionary efforts. ${ }^{4}$ This positive link stands in stark contrast to the negative attention Jesuit conversion efforts

$1 \quad$ Koasek Tribal Recognition: Comments in open meeting of the Vermont Commission on Native American Affairs. June 26, 2012. Statement of Nathan Pero, Chief, Koasek (Cowasuck) Traditional Band of the Sovereign Abenaki Nation. Recording on file with the Vermont Department of Historic Preservation.

2 The yet recognized Koasek (Cowasuck) Traditional Band of the Sovereign Abenaki Nation should not be confused with the Vermont state recognized Koasek Traditional Band of the Koas Abenaki Nation. See S. Res.129 (Act 106), Sess. of 2012 (VT. 2012), https://legislature. vermont.gov/bill/status/2012/S.129 (accessed January 14, 2021).

3 The author served two terms on the gubernatorially appointed Vermont Commission on Native American Affairs, August 2011 to August 2015.

4 The reader will note that the author employs the terms Native American and First Nations. The body of this work draws on literature from both the United States and Canada. It is the convention to refer to Indigenous peoples in the United States as "Native Americans" and those in Canada as "First Nations." Both of these terms are colonially contrived exonyms that imply a cohesive and homogeneous nature between numerous individual Native nations of North America, when no such cohesive nature existed. For a more complete discussion of this topic, see Gordon Gibson, A New Look at Canadian Indian Policy: Respect the Collective; Promote the Individual (Vancouver, BC: Fraser Institute, 20o9) and Michael Yellow Bird, 
have attracted in several outlets of academic literature, where researchers portray the Jesuits as causing damaging social change within Native societies. ${ }^{5}$

In this paper, I explore the relationship among the modern Western Abenaki, their eighteenth-century ancestors, and Jesuit missionaries, as it relates to identity politics and recognition by the State of Vermont. I begin this brief précis of Western Abenaki interaction with French Jesuit missionaries by first defining the identity of the Abenaki people and the delineation of their homeland. Next, I recount the known history and archaeology of JesuitAbenaki interactions in that same region, before returning to the topic of how modern Abenaki people have succeeded and failed in employing their association with Jesuit missionaries as an aid to their struggle for recognition by twenty-first-century governments.

\section{The Abenaki: The People of the Dawnland}

The Abenaki are a collective of Algonquin-speaking Native American and First Nations bands of the Eastern Woodlands culture area. ${ }^{6}$ The name "Abenaki" is a European corruption of an exonym uttered by the neighboring Montagnais/ Innu nation. ${ }^{7}$ The Innu term for "People of the Dawnland" (8abanaki8ek) was recorded by a Jesuit in his late seventeenth-century dictionary. ${ }^{8}$ The term was

"What We Want to Be Called: Indigenous Peoples' Perspectives on Racial and Ethnic Identity Labels," American Indian Quarterly 23, no. 2 (Spring 1999): 1-21.

5 Many authors have made qualitative comments in their works, mentioning cultural destruction that came along with Jesuit missionaries. These negative effects have been attributed to either the proselytization efforts or the inadvertent accompaniment of European diseases. For critique of proselytization efforts, see James Axtell, Beyond 1492: Encounters in Colonial North America (Oxford: Oxford University Press, 1992); Bruce G. Trigger, Natives and Newcomers: Canada's "Heroic Age" Reconsidered (Montreal: McGillQueen's University Press, 1986), 226-97.

6 It is the convention among anthropologists to classify Native American people into language derived culture groups and ecologically dependent culture areas. For a more specific discussion of the Abenaki language and its relation to the Algonquin language group, see the works of Gordon Day compiled in Michael K. Foster and William Cowen, eds., Search of New England's Native Past: Selected Essays by Gordon M. Day (Amherst: University of Massachusetts Press, 1998).

$7 \quad$ The group referred to as Les Montagnais by the French prefer to use their endonym of Innu. See Paul Charest "Les Montagnais ou Innus," in Le Nord: Habitants et mutations, ed. Gérard Duhaime (Quebec: Presses de l'Université Laval 2001), 37-52.

8 Jesuit Bonaventure Fabvre (1655-1701) resided in Canada from 1679 to 1693. See Bonaventure Fabvre, Racines montagnaises, trans. Lorenzo Angers and Gerard McNulty (Québec: Laval University Press, 1970). 
adapted into French as abénaquis or alternately abenaquioicts. ${ }^{9}$ The Abenaki peoples have been divided by anthropologists into two culture groups, the Eastern Abenaki and Western Abenaki. ${ }^{10}$

Ethnohistorical evidence indicates that Abenaki peoples defined their territory (N'dakina) in terms of river drainages. ${ }^{11}$ The Eastern Abenaki territory is bounded by the Merrimack and Saco River drainages to the northwest, the greater Penobscot River Valley to the northeast, and the Atlantic Ocean to the south, ${ }^{12}$ the Western Abenaki territory is bounded by the Lake Champlain/ Richelieu River Valley in the west and the White Mountains of New Hampshire in the east. ${ }^{13}$ The White Mountains function as a geological boundary between the Connecticut River Valley and the Saco and Merrimack River Valleys. The geographic location along the northeastern seaboard gave the "People of the Dawnland" their name, as they inhabit the land where the morning light first touches the continent (Figure 1).

Additionally, the specific topography of Vermont plays a prominent role in a creation myth attributed to the Western Abenaki people. A mythical being by the name of Ojihozo is said to have created the Lake Champlain Valley, the Adirondack Mountains that delineate the valley to the west, and the Green

9 Gordon Day "Western Abenaki," in Handbook of the North American Indians, vol. 15: Northeast, ed. William C. Sturtevant (Washington, DC: Smithsonian Institution, 1978), 14859 , here 148.

10 It is important to note that these designations are largely ethnolinguistic and were derived as a product of early anthropological study. Due to a lack of linguistic evidence from the area of the White Mountains of New Hampshire, the exact boundary between the Eastern and Western Abenaki languages remains unclear. See Day, "Western Abenaki," 148. The Western and Eastern Abenaki (or Penobscot) along with the Mi'kmaq, Maliseet, Passamaquoddy, comprise the Wabanaki people who have historically been members of the loose political affiliation known as the Wabanaki Confederacy. The confederacy was formed in 1606 as a group alliance with the French to protect collective Wabanaki interests from their neighbors to the west, the Iroquois Confederacy. See Frank G. Speck, "The Eastern Algonkian Wabanaki Confederacy," American Anthropologist, new series, 17, no. 3 (1915): 492-508; Dean Snow, "Eastern Abenaki," in Handbook of the North American Indians, 137-47, here 137.

11 Snow, "Eastern Abenaki," 137.

12 Snow, "Eastern Abenaki," 137-38.

13 Colin G. Calloway, The Western Abenaki of Vermont 1600-1800: War, Migration and the Survival of an Indian People (Norman: University Press of Oklahoma, 1990), 7; Gordon Day "Abenaki Place-Names in the Champlain Valley," International Journal of American Linguistics 47, no. 2 (1981): 239-41. Day takes a relatively in-depth look at several historic Abenaki toponyms including Bitawbagok, or "the waters between" for Lake Champlain. For an in-depth discussion of boundaries in the Lake Champlain Richelieu River Valley, see Andrew R. Beaupré, "Creating the Border: Defining, Enforcing and Reasserting Physical and Ethnic Borderzone Spaces during the Sixteenth, Seventeenth and Eighteenth Centuries in the Lake Champlain Richelieu River Valley" (unpublished PhD diss., The College of William and Mary, 2017). 


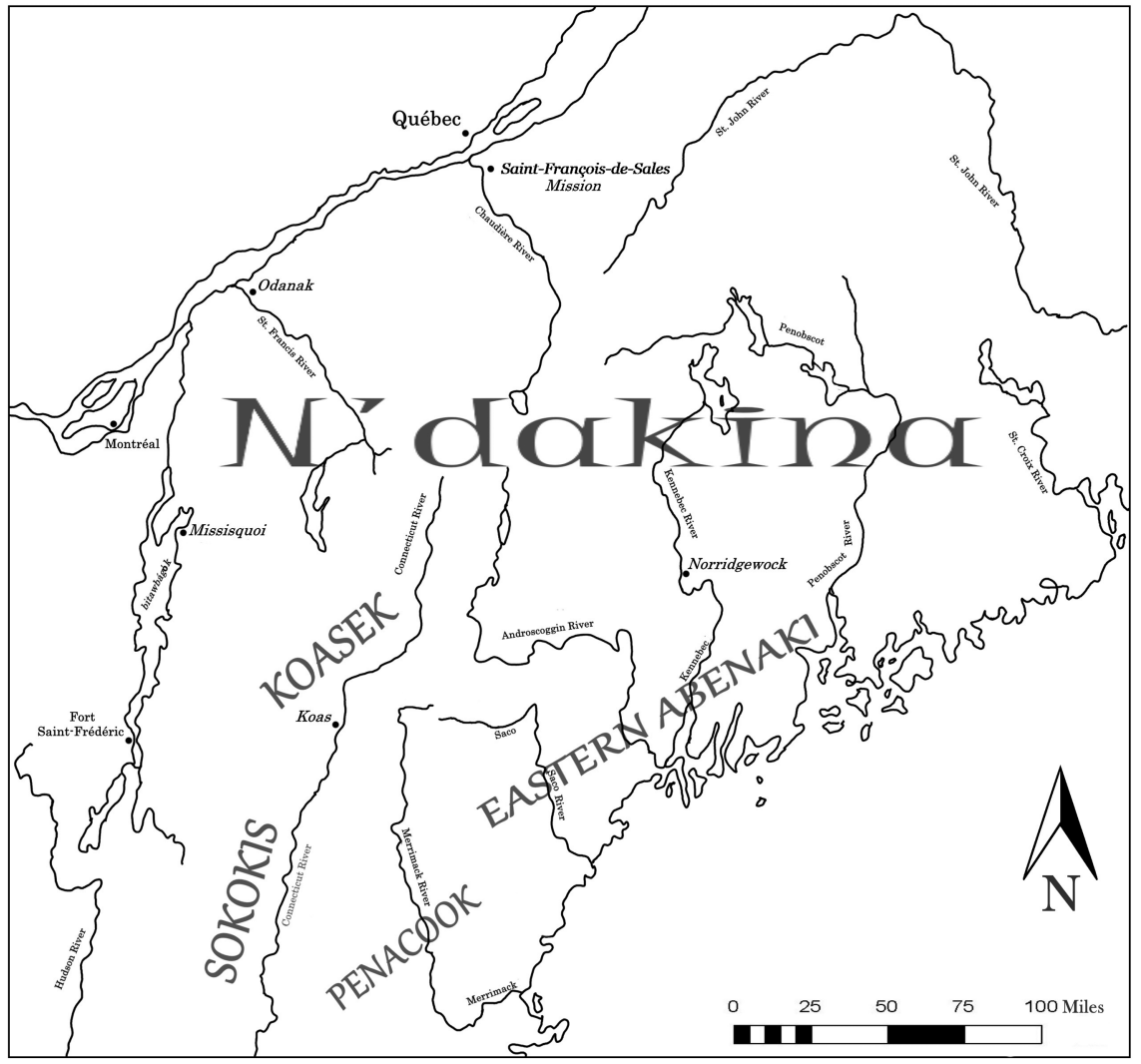

FIGURE 1 A map of the Western Abenaki Homeland showing missions and several principal villages

Mountains that delineate it to the east. Ojihozo was so pleased with his creation that he decided to spend all eternity in the region and transformed himself into a large monolith in Lake Champlain. The lake was known as bitawbágók or "the waters between." ${ }^{4}$ Consensus within the academy, citing both archaeological and historical sources, places the late prehistoric and protohistoric Western Abenaki homeland as bounded by "Lake Champlain on the west to the White Mountains on the east, and from southern Quebec to the VermontMassachusetts border."15

14 Day "Western Abenaki," 157; Day "Abenaki Place-Names," 240; and Giovanna M. Peebles, et al., Lake Champlain Voyages of Discovery: Bringing History Home (Montpelier: Vermont Division of Historic Preservation, 2009), 6.

Day, "Western Abenaki," 7. 
Within the Eastern and Western divisions of the Abenaki people, toponym-related ethnonyms are used to identify subgroups that reside within principal villages or localities. The primary Western Abenaki villages/ ethnicities include the Missisquoi (at the flint), referring to an Abenaki-utilized chert quarry near Swanton, Vermont. Penacook (at the falling bank), is the name of a village site in what is now Concord, New Hampshire. The Sokoki or Squakheag refers to a band that inhabited the upper reaches of the Connecticut River Valley. ${ }^{16}$ Sokoki translates to "the one's who broken-up, broke away."17 Finally, the Cowasuck or Koasek (white pines place), refers to the Lower Coos Intervals along the Connecticut River, and to the large old-growth forest that stood in the Connecticut River Valley until the 193os. Variants of this place name include the French Koés and the English Cohass, Cohoss, and Coos. ${ }^{18}$ The shores of the Connecticut River are home to the four groups that use some form of this toponym in their band name, the Koasek (Cowasuck) Traditional Band of the Sovereign Abenaki Nation, the Vermont state recognized Koasek Traditional Band of the Koas Abenaki Nation and Nulhegan Band of the Coosuk Abenaki Nation, as well as the New Hampshire-based Cowasuck Band of the Pennacook Abenaki People.

\section{Missionary Activity in Koasek Abenaki Territory}

\section{The Historical Narrative}

It is an established refrain that Catholic missionaries, specifically the Order of Friars Minor Recollet (the Recollets) and the Society of Jesus (Jesuits) came to New France with the primary goal of converting Native peoples to Catholicism. ${ }^{19}$ Researchers interested in Jesuit missionaries in New France

16 Day, "Western Abenaki," 148, 159. The term Sokoki is currently used as a portion of the official name of the Vermont State recognized band, St. Francis/ Sokoki Band of the Sovereign Republic of the Abenaki Nation of Missisquoi.

17 Margaret Bruchac, "Founding Schaghticoke and Odanak," in Raid on Deerfield: The Many Stories of 1704 (2005), https://repository.upenn.edu/anthro_papers/145 (accessed January 14, 2021); Gordon Day, The Identity of the Saint-Francis Indians, Mercury Series Paper 71 (Ottawa: National Museum of Man, Canadian Ethnology Service, 1981), 5-6, 107-17. In this case, the "breaking away" may refer to the Sokoki forming the nucleus of the refugee community at Odanak, Quebec in the late seventeenth century. The Abenaki word Odanak translates to "village."

18 Day, "Western Abenaki," 159.

19 James Axtell, The Invasion within: The Contest of Cultures in Colonial North America (New York: Oxford University Press, 1985), 38. There are countless texts that address Jesuit activities in New France. See, for example, Carole Blackburn, Harvest of Souls: The Jesuit 
have an immense resource in the compiled and published Relations des jésuites de la Nouvelle-France. ${ }^{20}$ These documents were written annually, compiled, edited, and printed beginning in 1632 and ending in 1673 . However, by the time Jesuit missionary activity with the Western Abenaki became firmly established early in the eighteenth century, the Relations were no longer being published. ${ }^{21}$

As the eighteenth century began and European powers increasingly contested each other's colonial hegemony, English forces exerted greater control over northern New England. During these conflicts, the Abenaki remained allies of the French..$^{22}$ Following the French and Indigenous attack known as the Deerfield Raid (1704), tensions rose between the English and the Frenchallied Abenaki people in the Connecticut River Valley. ${ }^{23}$ In June 1704, Marquis de Vaudreuil (1643-1725), the governor general of New France, offered the Cowasucks (Koaseks) refuge at the resurrected mission village of Sillery, near Quebec City, where they could be better protected. ${ }^{24}$ The Koaseks refused refuge, preferring to stay in their homeland at the Cowass (Koas).$^{25}$ Following the decision to stay, and prior to 1713 , the Jesuits established a mission to the

Missions and Colonialism in North America, 1632-1650 (Montreal: McGill-Queen's University Press, 2000); Luca Codignola, "Competing Networks: Roman Catholic Ecclesiastics in French North America, 1610-58," The Canadian Historical Review 80, no. 4 (1999): 539-84; Cornelius Jaenen, The Role of the Church in New France (Toronto: McGraw-Hill Ryerson, 1976); Brownen McShea, Apostles of Empire: The Jesuits and New France (Lincoln, NE: University of Nebraska Press, 2019). For a comprehensive historiography on the Jesuits in New France, see Luca Codignola, "The Historiography on the Jesuits of New France," Jesuit Historiography Online, ed. Robert A. Maryks, https://referenceworks.brillonline.com/entries/jesuit-historiographyonline/the-historiography-on-the-jesuits-of-new-france-COM_220170 (accessed January 15, 2021).

20 Thwaites, Jesuit Relations in its seventy-three volumes is the most common edition of the work.

21 Thwaites, Jesuit Relations, does include documents dating up to 1791, yet has little to offer referring to the Western Abenaki peoples of Vermont.

22 Thwaites, Jesuit Relations, 67:13.

23 For a discussion of the Deerfield Raid and its aftermath, see Evan Haefeli and Kevin Sweeney, Captors and Captives: The 1704 French and Indian Raid on Deerfield (Amherst: University of Massachusetts Press, 2003).

24 Calloway, Western Abenaki, 104-5. Sillery is located seven kilometers (4.34 miles) southwest of the city wall of Quebec City and had been the location of a previous Jesuit mission village that had accepted Sokokis and other Abenaki in the 167os; Calloway, Dawnland Encounters: Indians and Europeans in Northern New England (Hanover, NH University Press of New England, 1991), 68. See also James P. Ronda, "The Sillery Experiment: A Jesuit-Indian Village in New France, 1637-1663," American Indian Culture and Research Journal 3, no. 1 (1979): 1-18.

25 Calloway, Western Abenaki, 104-5 and Colin G. Calloway, Dawnland Encounters: Indians and Europeans in Northern New England (Lebanon, NH: University Press of New England, 1991), 151-52; for Calloway's translation of the Speech of the Abenaki Indians of Cowasuck to the Governor-General, June 13, 1715, National Archives of Canada, MG 1 F3, 2:407-10. 
Cowasuck at the Cowass. ${ }^{26}$ The specific maps and documents referred to by Chief Pero relate to this particular period in the history of Cowasuck and Jesuit interaction in the Connecticut River Valley. While the historical data surrounding the Jesuits' activity in the Connecticut River Valley may be limited, the role of Catholic missionaries in N'dakina (the greater Abenaki homeland) is well established.

Oral traditions among the Missisquoi and Koasek Native peoples indicate that French Catholic missionaries may have been active in Abenaki villages along the Lake Champlain and southern Richelieu River as early as $1615 .{ }^{27}$ While there is no clear documentary evidence to indicate such, this story is possible, considering the Recollets had established a mission at Quebec in May $1615 .{ }^{28}$

The first well-documented visit to the Western Abenaki homeland by a Jesuit missionary was by Isaac Jogues (1607-46), who traveled through the Champlain Valley interacting with members of the Sokokis Band before his death on October 18, 1646.29 In 1646, Jesuit Gabriel Druillettes (1610-81) made

26 Calloway, Western Abenaki, 46-48, and Calloway, Dawnland, 59. Calloway mentions the mission at Cowass being shown on a French map, presumably the Aubry map discussed later. Calloway offers no other evidence of this construction.

27 This fact is mentioned in the editorial commentary of the primary document compilation in Calloway, Dawnland, 59. Additionally, members of the Abenaki Community self-selected to offer information, comments and concerns about my work, as well as other archaeologist's research, in an attempt to add color to my opinions. While most of my conversations with these individuals may not be cited directly here, they have informed my work on Abenaki/ missionary interaction.

28 Anicka Fast, "Helping 'our Canadian Brothers': Early Recollect Missiology as an Experiment in Christian Community, 1615-1629," Journal of Early Modern Christianity 5, no. 1 (2018): 75108, here 82; Codignola, "Competing Networks," 540-41. For a more complete introduction to the Recollet Missionaries in New France, see Caroline Galland, Pour la gloire de Dieu et du Roy: Les récollets en Nouvelle-France aux XVII et XVIII siècles (Paris: Éditions du Cerf, 2012). The Recollet were a branch of the Order of Friars Minor, or Franciscans. The first French Jesuit mission explicitly sent to an Abenaki people was established on Mount Desert Island, Maine in 1611. The Saint-Sauveur Mission was therefore within Eastern Abenaki territory. The coast of Maine was a contested border region between the English territory of Virginia and the French colony of Acadia. The mission was short lived due to a 1613 British raid which destroyed the facility and killed Brother Gilbert du Thet (c.1575-1613), among others. See Matteo Binasco, "Few, Uncooperative, and Endangered: The Troubled Activity of the Roman Catholic Missionaries in Acadia (1610-1710)," Reformation and Renaissance Review:Journal of the Society for Reformation Studies 8, no. 3 (20o6): 321-47, here 323-28. The remains of the mission have not been recovered archaeologically, and records offer no clear indication as to exactly where the mission was located.

29 David Farmer, Oxford Dictionary of Saints (New York: Oxford University Press, 2004), 274-75; and Robert A. Goldstein, French-Iroquois Diplomatic and Military Relations (Paris: Mouton, 1969), 69, 75-76. 
several journeys inland to the Western Abenaki, including the Penacooks and the Sokokis while based at a mission on the Kennebec River. In his writings, Druillettes spoke of the Connecticut River as, "River of the Sokokis." ${ }^{30}$ On the feast day of Sainte-Anne, July 26, 1666, Fort Saint-Anne was completed on Isle LaMotte, within bitawbágók. ${ }^{31}$ This location was previously known as a gathering place for Native peoples, where missionaries had preached to both Abenaki and Iroquois as early as the 1640 s. $^{32}$ During the period that Fort Sainte-Anne was occupied (1666-90), missionaries may have also proselytized on the eastern shore of the lake at or near the village of Missisquoi. 33

During the 1670s, a group of refugee Abenaki, and other Algonquin speaking peoples, founded Odanak along a tributary of the St. Lawrence River. In 1709, the Mission de Saint-François-de-Sales was relocated from the mouth of the Chaudière River near Quebec City to Odana.$^{34}$ To this day, the Odanak Indian Reserve No 12 remains the seat of power for the Conseil des Abenakis in the province of Québec.

In the early 1730s, French forces constructed Fort Saint-Frédéric at the south end of Lake Champlain. Along with the French troops came habitants to farm the local seigneurie, and a series of Jesuits to attend to the settlers' spiritual needs. ${ }^{35}$ During French control of the region (1731-57), records of baptisms and burials indicate Abenaki people traveled from Missisquoi, and elsewhere, to the fort to access the services of the Chaplain. ${ }^{36}$ Circa 1743 , the

$30 \quad$ Calloway, Western Abenaki, 11.

31 Jack Verney, The Good Regiment: The Carignan-Salières Regiment in Canada, 1665-1668 (Montreal: McGill-Queen's University Press, 1991), 32-33; Thwaites, Jesuit Relations, 50:153-83.

32 Guy Omeron Coolidge, The French Occupation of the Champlain Valley from 1609 to 1759 (New York: Purple Mountain Press 1999 [1939]), 28-29. The Archdiocese of Burlington, Vermont wished to commemorate the site of Fort Saint-Anne as the location where Mass was first celebrated within the modern State of Vermont and selected the site for a shrine to SainteAnne in the late nineteenth century.

33 Calloway, Western Abenaki, 46. Calloway mentions a 1690 mission at Missisquoi. The mission to which he is referring is most likely Fort Sainte-Anne. Calloway also cites the Vermont Historical Gazetteer as documenting the construction of the first stone church in Vermont on the banks of the Missisquoi River in 170o. This source has been proven to hold many nineteenth-century historical falsehoods and erroneous statements.

34 Day, Identity of the Saint Francis, 5 .

35 Peebles et al., Lake Champlain, 6. Coolidge, French, 175 provides a list of chaplains assigned to Fort Saint-Frédéric.

36 William A. Haviland and Marjory W. Power, The Original Vermonters: Native Inhabitants; Past and Present (Hanover, NH: University Press of New England, 1994), 232-34. Excerpts from these parish records have been published in numerous places. Coolidge, French, 131-65, 179218 uses his own translations of the documents to complete his biographical index of French persons in the Lake Champlain Valley to 1759. 
French crown determined that Missisquoi warranted its own mission. Jesuit Étienne Lauverjat (1679-1761) was dispatched to the village in 1744 and was in residence until $1749 \cdot{ }^{37} \mathrm{~A}$ Sulpician, Claude Mathevet (1717-81), is also noted as visiting Missisquoi in the mid-175os. ${ }^{38}$ To this day, the geographic area around the mouth of the Missisquoi River continues to be the seat of St. Francis/ Sokoki Band of the Sovereign Republic of the Abenaki Nation of Missisquoi tribal government. ${ }^{39}$

\section{The Archaeological Record}

Jesuit missions and related sites in North America have been at the center of many archaeological investigations. ${ }^{40}$ Yet, much like the documentary record, archaeology of Jesuit missionary activities among the Western Abenaki of Vermont is somewhat limited. The recorded visits of missionary priests to the Koasek Abenaki were brief. ${ }^{41}$ Identifying brief events in the archaeological record is limited by what remains are left in the landscape.

When one examines the archaeology of Jesuit involvement in the Upper Connecticut Valley along the Koas, clear evidence is not forthcoming. A major reason for lack of archaeological evidence may indeed be the lack of archaeological investigation. The vast majority of archaeological research undertaken in North America is cultural resource management in order for construction projects to be in compliance with state and federal permitting processes. The Upper Connecticut River Valley has seen little development since modern historic preservation law took effect in the latter half of the twentieth century. The region is largely economically depressed and archaeological research has been limited.

37 Haviland and Power, Original Vermonters, 234-35; Library and Archives of Canada MG1 C11A, 81:31-32, translated in Calloway, Dawnland, 163.

38 Gordon Day, The Mots Loups of Father Mathevet, Publication in Ethnology, 8 (Ottawa: National Museum of Man, 1975).

39 The St. Francis/ Sokoki Band of the Sovereign Republic of the Abenaki Nation of Missisquoi, The Missisquoi Abenaki Application for Vermont State Recognition, Prepared by the Abenaki Nation at Missisquoi, St. Francis-Sokoki Band (Swanton, VT, 2013).

40 See other contributions in this issue. Additionally, see Charles J. Rinehart, Crucifixes and Medallions: Their Role at Fort Michilimackinac, Volumes in Historical Archaeology, 11 (Columbia: South Carolina Institute of Archaeology and Anthropology, 199o); Daniel Simoneau, "The Seminary of Québec site: From New France's Earliest Farm to Its First Religious Institution," Post-Medieval Archaeology 43 no. 1 (2009): 213-28; Wilfred Jury and Elsie McLeod Jury, Sainte Marie among the Huron (Toronto: Oxford University Press, 1954), among many others.

41 Gordon Day, "Dartmouth and Saint Francis," Dartmouth Alumni Magazine (1959): 28-30. 
Within the prescribed homeland of the Koasek people, now known as Newbury, Vermont, and Haverhill, New Hampshire, numerous stories abound about the recovery of seventeenth- and eighteenth-century European artifacts in the floodplains around the Connecticut River. When pressed, members of the local community are not forthcoming to produce said recovered artifacts. Archaeological evidence of Native habitation in the Koasek and Missisquoi areas is beyond contestation, and as such has been noted in Vermont State statute. ${ }^{42}$ However, at the time of this writing, no historic period archaeological site yielding Native and/ or colonial artifacts indicative of a mission site has been identified or excavated by professional archaeologists in the Koas Meadows. ${ }^{43}$

One archaeological site, Fort Hill in Hinsdale, New Hampshire, has been employed to defend the existence of Jesuit activity in the Upper Connecticut River Valley. Fort Hill is a proto-historic/ early colonial period Squakheag (Sokoki) Abenaki village, located on a high bluff above a tributary of the Connecticut. ${ }^{44}$ The site was determined to date from the mid-16oos, specifically a six-month period between 1663 and 1664 . The artifact assemblage recovered at Fort Hill included a number of so-called Jesuit rings (Figure 2).

Jesuit activity at Native American sites has often been identified through the presence of religious material culture in the archaeological record. Crosses, crucifixes, and religious medallions are well-documented in the archaeological record of Native sites in New France, yet not all archaeologists believe these artifacts are indicative of Jesuit proselytization. ${ }^{45}$ Jesuit rings, now more

42 Sec. 1.1 V.S.A. § 851 .

43 The reader should note that while no mission sites have been recovered in the Koas, the larger areas of Vermont, northern New England, and southern Quebec have seen archaeological activity at sites of Catholic missions. For discussion of Fort Saint-Anne, see Jessica Desany, "Enshrining the Past: The Early Archaeology of Fort St. Anne, Isle La Motte, Vermont," The Journal of Vermont Archaeology 1, no. 1 (2006): 40-53; Geneviève Treyvaud and Michel Plourde, Les Abénakis d'Odanak, un voyage archéologique (Odanak: Société historique d'Odanak, 2017); Charles L. Fisher, and Paul R. Huey "Style Wars in the Wilderness: The Colonial Forts at Crown Point," in The Archaeology of French and Indian War Frontier Forts, Lawrence E. Babits and Stephanie Gandulla, eds. (Gainesville: University of Florida Press, 2013); Huey, "The French Village at Crown Point: Where Was It?," New York State Archaeological Association Newsletter 5, no. 2 (2009): 1-5; Harold E. L. Prins and Bruce Bourque, "Norridgewock Village Translocation on the New England-Acadian Frontier," Man in the Northeast 33 (1987): 28-31.

44 Peter A. Thomas, "In the Maelstrom of Change: The Indian Trade and Cultural Process in the Middle Connecticut River Valley: $1635^{-1665}$ " (unpublished PhD diss., University of Massachusetts-Amherst, 1979).

45 For examples of archaeologists who consider French religious material culture as holding no special significance above any other trade good recovered in the archaeological record, 


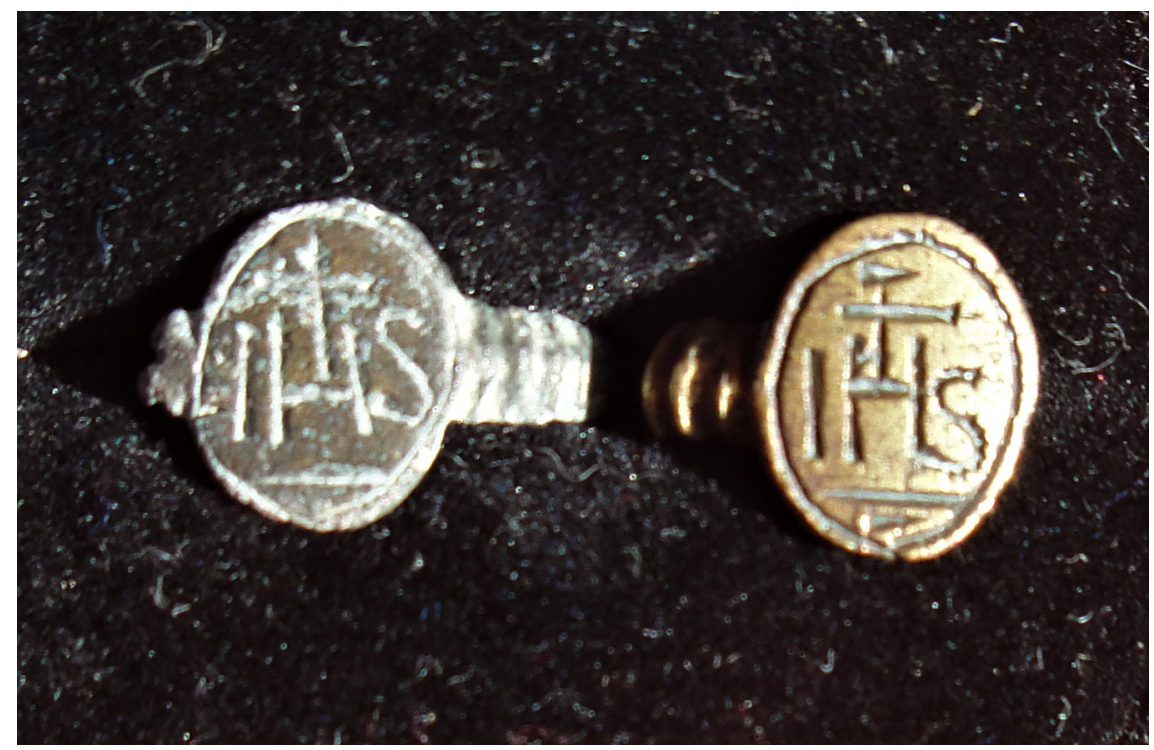

FIGURE 2 The plaque or Jesuit rings recovered from the Fort Hill Site archaeological site along the Connecticut River in southern New Hampshire PHOTO COURTESY OF PETER THOMAS

appropriately referred to by the descriptive term "plaque rings," are another class of religious related artifacts. These rings were once thought to have been gifted to Native converts only after learning the catechism. ${ }^{46}$ The majority of archaeological literature is now of the opinion that while some of these rings did pass from Jesuits to Native converts, traders saw the Native American interest in these items and began copying similar motifs for use in a purely economic

see Kurt A. Jordan, The Archaeology of the Iroquois Restoration: Settlement, Housing and Economy at a Dispersed Seneca Community, ca. A.D. 1715-1754 (unpublished PhD diss., New York University, 2002); Marcel Moussette, "Le medailles religieuses, une forme de l'imagerie baroque en Nouvelle-France," Les cahiers des Dix 55 (2001): 295-329. For examples of archaeologists who believe religious material culture recovered in New France deserve some special treatment as sacred, see Andrew R. Beaupré, "Sacred or Secular: Religious Materiality of the French Colonial Frontier" (MA thesis, Western Michigan University, 2011); José António Brandão and Michael S. Nassaney, "Suffering for Jesus: Penitential Practices at Fort St. Joseph (Niles, MI) During the French Regime," The Catholic Historical Review 94, no. 3 (2008): 476-99. Rinehart, Crucifixes; William R Fitzgerald, Dean H. Knight, and Paul A. Lennox, "Catholic Devotional Items from Seventeenth-Century Ontario Sites," Arch Notes: Newsletter of Ontario Archaeological Society 94 no. 2 (1994): 9-19.

46 Calloway, Western Abenaki, 46; Additionally, archaeologists and historians alike cite a particular passage by Jean Enjalran that discusses the importance of material culture in conversation. See Thwaites, Jesuit Relations 6o:133-39. 
exchange system. ${ }^{47}$ When Peter Thomas initially published about FrenchIndian contact in the Connecticut River Valley, it was understood that Jesuit rings were handed out to Native converts after catechism classes. Jesuit rings in Native contexts therefore indicated a Jesuit presence. ${ }^{48}$ Thomas acknowledges this fact, yet he states that "the actual establishment of a Jesuit mission in the Connecticut Valley on the very borders of the English colonial sphere seems highly unlikely" 49 Thomas goes on to say that the origin of Jesuit rings recovered at Fort Hill is more than likely the St. Francis Mission. He argues that the rings were most likely carried as personal possessions with the Abenaki people from the St. Lawrence River Valley to the Connecticut River. Regardless of Thomas's initial interpretations, other researchers have employed the Jesuit rings recovered at Fort Hill as evidence of the existence of a Jesuit mission in the valley. ${ }^{50}$

As outlined above, there is abundant evidence that Vermont was the historical home of multiple Abenaki peoples. Indeed, the original bill that created the Vermont Commission on Native American Affairs simply stated that "all Native American people who reside in Vermont are a minority population" without offering specifics as to who these people were. ${ }^{51}$ While it was a start, this bill proved inadequate to the Abenaki who wanted meaningful concessions to be made. Subsequent legislation outlined the process for the recognition of tribal governments by the State of Vermont. When scholars can cite the Abenaki association with the geographic area of Vermont as a foregone conclusion, it has been difficult to convince modern Native groups that they must prove their identity to gain state recognition.

\section{Vermont State Recognition ${ }^{52}$}

As defined in Vermont Act 107 of 2010, recognition is defined by Vermont State Statute as acknowledgement "as a Native American Indian tribe by the Vermont

47 Caroline Mercier, Bijoux de pacotille ou objets de piété?: Les bagues dites jésuites revisitées à partir des collections archéologiques du Québec (Québec: Cahiers d'archéologie du Celat, 2012); Carol I. Mason, "Jesuit Rings, Jesuits and Chronology," Midcontinental Journal of Archaeology 27 no. 1 (2003): 233-57; Carol I. Mason and Kathleen L. Ehrhardt, "Iconographic (Jesuit) Rings in European/ Native Exchange." French Colonial History 10 no. 1 (2009): 55-73.

48 Calloway, Western Abenaki, 46.

49 Peter Thomas, "Jesuit Rings: Evidence of French-Indian Contact in the Connecticut River Valley," Historical Archaeology 7 (1973): 54-57.

50 Calloway, Western Abenaki, 46; Haviland and Power, Original, 206-7.

$51 \quad$ Sec. 1. 1 V.S.A. $§ 852$.

$5^{2}$ There is a surprising dearth of anthropological publication relating to state recognition of Native American groups. The majority of publication is in the fields of law or published in 
general assembly" 53 This designation is clearly modeled on federal tribal recognition. However, unlike federal recognition, Vermont State "recognition of a Native American Indian tribe shall not be construed to create, extend, or form the basis of any right or claim to land or real estate in Vermont or right to conduct any gambling activities prohibited by law." ${ }^{44}$ State-recognized tribes are eligible to place "Indian-made" on their crafts, as well as to be recognized on school rolls as Indian, and therefore enable public school systems to apply for federal Title vil Indian education funds. ${ }^{55}$

As mentioned above, I heard Chief Pero's statement in my role as a member of the Vermont Commission on Native American Affairs. By statute, the Vermont Commission on Native American Affairs was established to "recognize the historic and cultural contributions of Native Americans to Vermont, to protect and strengthen their heritage, and to address their needs in state policy, programs, and actions." Furthermore, the commission is charged with "providing technical assistance [...] to applicants for state recognition [...] reviewing each application, supporting documentation $[\ldots]$ and making recommendations for or against state recognition." ${ }^{56}$ The process of state recognition has been cited as a tactic by an oppressive state government to yet again control and subjugate Native peoples, peoples who would prefer the state within a State status granted to federally recognized tribes. ${ }^{57}$ Vermont is one of eleven states that house state-recognized tribes. Three of these states-Georgia, Maryland, and Vermont — have only state-recognized and no federally recognized tribes. ${ }^{58}$ While no federally recognized Abenaki Nation exists within

local newspaper articles in the localities directly associated with Native communities. See Martha Salazar, "State Recognition of American Indian Tribes," Legisbrief 24, no. 39 (2016); Laura Ruth Talbert, "Native American Graves Protection and Repatriation Act: Requiring Federal Recognition Digs Its Own Grave," American Indian Law Review 37, no. 1 (2012-13): 171-202; Alexa Koenig andJonathan Stein, "Federalism and the State Recognition of Native American Tribes: A Survey of State-Recognized Tribes and State Recognition Processes across the United States," Santa Clara Law Review 48, no. 1 (2008): 79-154.

53 Sec. 1. 1 VT. Stat. Ann. tit. 9A, § 851.

54 Sec. 1. 1 VT. Stat. Ann. tit. $9 A$, $\S 853$.

55 Two Vermont recognized bands, the Nulhegan Band of the Coosuk Abenaki Nation and St. Francis/Sokoki Band of the Sovereign Republic of the Abenaki Nation both have active title VII grant programs.

$56 \quad$ Sec. 1. 1 V.S.A. $\S 851$.

57 Wendell H. Oswalt, "This land was theirs": A Study of Native North Americans (New York: Oxford University Press, 2009), 462-74; Koasek Traditional Band of the Sovereign Abenaki Nation, Addendum to Vermont Native American Recognition Application Bill S. 222/S853. Chief Nathan E. Pero and Chief Paul Bunnell (Post Mills, VT, 2012).

58 Salazar, "State Recognition," 1. It is important to note that the federally recognized Stockbridge-Munsee Band of Mohican Indians, while now based in their post removal home 
the borders of the modern state of Vermont, four autonomous bands of the Abenaki people have gained state recognition.

The criteria for recognition by both the federal government ("BIA recognition") and recognition by the State of Vermont reference the necessity for historic and modern tribes to inhabit a specific geographic area. ${ }^{59}$ In Vermont, the applicant group must also provide documentary evidence that they have "historically maintained an organizational structure that exerts influence and authority over its members" and "an enduring community presence within the boundaries of Vermont that is documented by archaeology, ethnography, physical anthropology, history, folklore, or any other applicable scholarly research and data." 60 The explicit tie between identity, government and geographic delineation made by the above legislation has had a profound effect on Native groups in Abenaki country. ${ }^{61}$

While the commission stressed that recognition was not strictly about identity but a legal agreement between the tribal government and the government of a state, applications for recognition often took the tone of defending Abenaki existence in the past, as opposed to establishing specific ties between historically known Native peoples and modern Abenaki tribal or band governments. ${ }^{62}$

The reliance of the state-recognition process on the documentation of an organizational structure, applied to peoples that had no written records prior to Samuel de Champlain's (c.1570-1635) arrival in the region in 1608 , carries with it a ring of government bureaucracy. While the criterion does stipulate that archaeological data may be employed to defend the enduring presence of the community, proving a direct line of descent between archaeological remains and a living population is not a foregone conclusion. Vermont State recognition legislation privileges European-style written documentation over other forms of information transmission, such as Native American oral traditions. At prima facie inspection, it would seem rather obvious for modern Native American bands to employ the notoriously comprehensive records

of Wisconsin, claim the southwestern corner of Vermont as a portion of their ancestral homeland.

5925 CFR Part 83.7b; VT. Stat. Ann. tit. 9A, § 853 .

6 o VT. Stat. Ann. tit. 9A, § 853 .

61 Oswalt, This Land, 462-74.

62 Abenaki Nation at Missisquoi, St. Francis-Sokoki Band "St. Francis/ Sokoki Application," Koasek Traditional Band of the Sovereign Abenaki Nation, Vermont Native American Recognition Application Bill S. 222/S853. Chief Nathan E. Pero and Chief Paul Bunnell (Post Mills, VT, 2012); Koasek Traditional Band of the Koas Abenaki Nation, Application for Vermont State Recognition. Prepared by the Koasek Traditional Band of the Abenaki Nation, Chief Nancy Millette Doucet (Newbury, VT, 2010). 
of Jesuit missionaries to defend their geographic and governmental claims. Indeed, two other Vermont recognized Abenaki bands, the St. Francis/Sokoki Band of the Sovereign Republic of the Abenaki Nation of Missisquoi and The Koasek Traditional Band of the Koas Abenaki Nation included documentary evidence of interactions with Jesuit missionaries in their applications for state recognition. ${ }^{63}$

\section{The Role of Jesuit History and Archaeology in Recognition Politics}

The St. Francis/Sokoki Band of the Sovereign Republic of the Abenaki Nation of Missisquoi cited documentary and archaeological evidence of Jesuit missions to their ancestors as a portion of their successful application for state recognition. ${ }^{64}$ To this day, the banks of the Missisquoi River in and around Swanton, Vermont, are often cited as the seat of power of the Western Abenaki people. Numerous documents from the French and British colonial periods record the presence of an Abenaki community at Missisquoi. Those documents include limited references to a missionary working out of Fort Sainte Anne on Isle Motte, established in 1666, and the possible establishment of a mission somewhere on the east shore of Lake Champlain in 1682. Documentary evidence relating to this seventeenth-century mission is vague at best.

Additional documentary evidence indicates the existence of two eighteenth-century Jesuit presences in the Champlain Valley. Those same documents indicate that the creation of these missions was more political than religious in nature. Soon after the establishment of Fort Saint-Frédéric on Lake Champlain in 1731, the Jesuits were called upon to do whatever was necessary to strengthen ties between the French and Abenaki peoples. ${ }^{65}$ A chaplain was assigned to the fort and began to keep parish records in 1732 . These records tell of some sixty baptisms and twenty burials of Abenaki, many of them from Missisquoi. Among the baptized are the children of Greylock (1675-1740), an adopted Abenaki war chief based at Missisquoi, who has been used as a symbol of Abenaki revitalization since the 1970s. In 1743, some years before Seven

63 St. Francis/ Sokoki Band makes explicit ties to the Missisquoi mission and records of Missisquoi Abenaki visiting the chaplain at Fort Saint-Frédéric. While the application of The Koasek Traditional Band of the Koas Abenaki Nation mentions the same mission referred to by Chief Pero.

64 The Abenaki Nation of Missisquoi, St. Francis-Sokoki Band, "The Missisquoi Abenaki Application for Vermont State Recognition" (Swanton, VT: Abenaki Nation at Missisquoi, St. Francis-Sokoki Band, 2013).

65 Haviland and Power, Original Vermonters, 233. 
Years' War (1756-63), the French constructed a mill and several other buildings at Missisquoi. Jesuit Étienne Lauverjat was sent to the village as a resident missionary. Unlike the mission at Fort Saint-Frédéric, and more akin to the purported mission at Koas, no robust record of Lauverjat's stay at Missisquoi has been recovered. ${ }^{66}$ Archaeological investigation in the Missisquoi Valley indicates near constant occupation at several sites from the Archaic period to the present day. However, no archaeological evidence of Jesuit activities, i.e., church, priests' house, or even objects of devotion have been recovered. The remains of a building identified as the chapel at Fort Saint-Frédéric is still visible, but the fort site was looted prior to its protection and has not been fully excavated.

Both Koasek bands' applications for state recognition included similar information on Jesuit missionaries to the Koas. It is intriguing that while no irrefutable historical or archaeological evidence of a mission in the Upper Connecticut Valley region exists, the two modern Vermont-based Abenaki groups that claim ancestral homeland in the area are still wedded to the idea of Jesuit presence to defend their geographically specific homeland and identity.

Koasek (Cowasuck) Traditional Band of the Sovereign Abenaki Nation's application includes a discussion of a circa 1713 map attributed to French Jesuit Joseph Aubry (1673-1756), which lists several mission sites including Koës encien village loup (Figure 3). Aubry's purpose in creating the map was to illustrate the location of French mission villages as the Treaty of Utrecht $\left(1713^{-15}\right)$ divided the area between the French and British crowns. ${ }^{67}$ Mention of the French settlement at Kowhas or Kohafser is then reproduced on a British map dating to 1755 (Figure 4). ${ }^{68}$ Both these maps show an abandoned native village at Lower Cowas near present-day Newbury, Vermont. This later British map was included in the state-recognized Koasek Traditional Band of the Koas Abenaki Nation application. ${ }^{69}$

66 Gordon Day, "Missisquoi: A New Look at an Old Village," Man in the Northeast 6 (Fall 1973): $51^{-} 57$, here 54 .

67 Joseph Aubry, S.J., Cartographe: Carte pour les hauteurs des terres et pour servir de Limitte, suivant la Paix, entre la France et l'Angleterre, suivant les mémoires du R.P. Aubry, Jésuite, 1715 [Rouen: Jos. Aubry, 1715], http://catalogue.bnf.fr/ark:/12148/cb413983958 (accessed January 14, 2021).

68 Thomas Jefferys, Cartographer: A map of the most inhabited part of New England containing the provinces of Massachusetts Bay and New Hampshire, with the colonies of KoneKtikut and Rhode Island, divided into counties and townships; The whole composed from actual surveys and its situation adjusted by astronomical observations [London: Thos. Jefferys, 1755], https:// www.loc.gov/item/74692155/ (accessed January 16, 2021).

69 Doucet, Koasek Traditional Band, 6. 


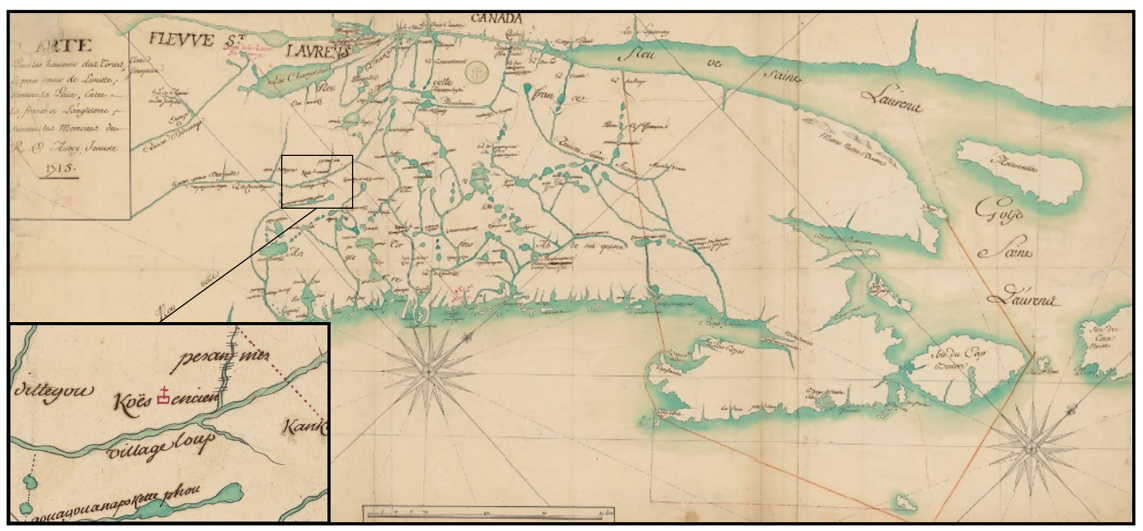

FIGURE 3 Aubry's 1715 map showing the locations of Abenaki mission villages. Bottom left, an enlargement of the Koas village. Carte pour les hauteurs des terres et pour servir de Limitte, suivant la Paix, entre la France et l'Angleterre, suivant les mémoires du R.P. Aubry, Jésuite, 1715.

MAP COURTESY OF BIBLIOTHÈQUE NATIONALE DE FRANCE

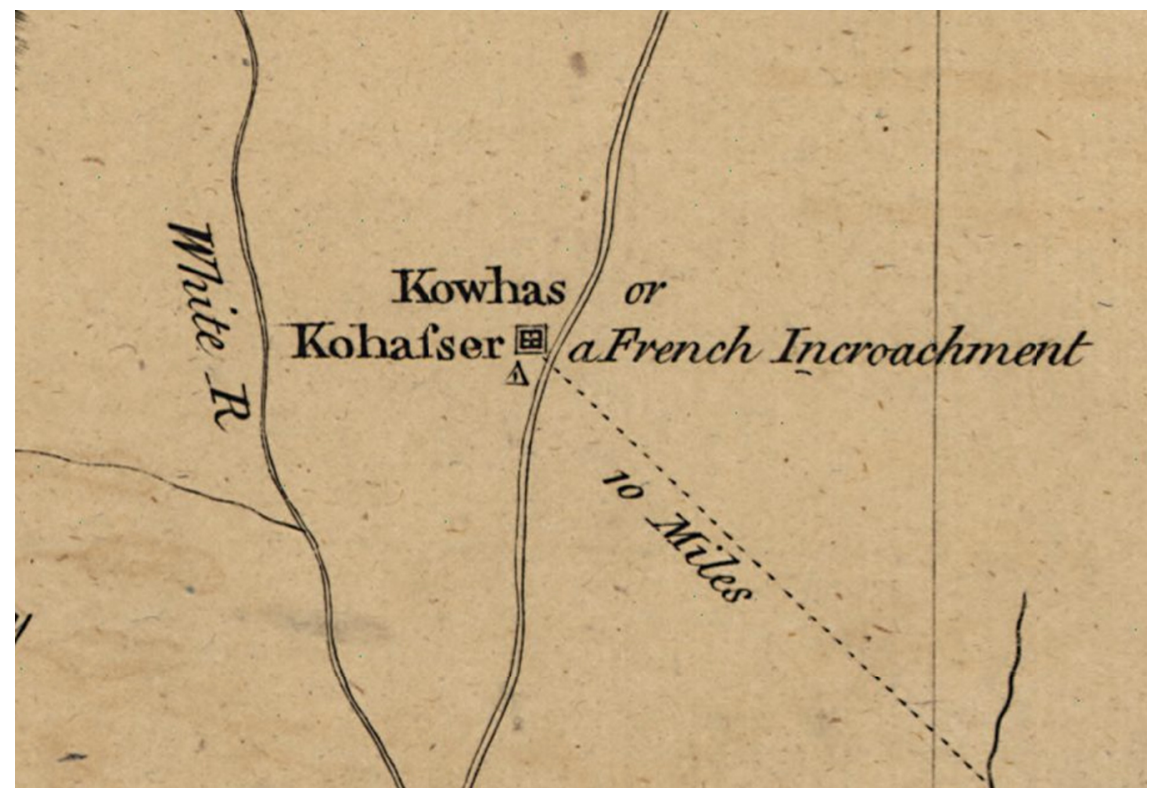

FIGURE 4 A fragment of a 1755 British map showing the former French mission village at the Koas. A map of the most inhabited part of New England: Containing the provinces of Massachusetts Bay and New Hampshire, with the colonies of KoneKtikut and Rhode Island, divided into counties and townships; The whole composed from actual surveys and its situation adjusted by astronomical observations.

MAP COURTESY OF THE LIBRARY OF CONGRESS, GEOGRAPHY AND MAP DIVISION 
Numerous secondary historical sources have included these maps as evidence of the existence of an Abenaki village in the Upper Connecticut Valley region through its association with the purported Jesuit mission. ${ }^{70}$ Indeed, Koasek (Cowasuck) Traditional Band of the Sovereign Abenaki Nation cited these secondary historical sources in their application for state recognition. Ironically, both maps indicate that the mission and native village were abandoned during the early eighteenth century (1713-15), undercutting the case for historical permanence of the applicant group within a specific geographic area. Further historical documentation through the mid-eighteenth century indicates that the Koas village was reoccupied and remained a stronghold of the Abenaki population into the early nineteenth century. However, other than these two maps, there is no documentation, currently known, to corroborate the existence of this mission. It is likely that some Jesuit archive holds a yet-unknown and unanalyzed treasure trove of information about the Koas mission.

\section{Conclusions}

When we revisit Chief Pero's words, "The Jesuit mission proves we were here. We know we existed because the Jesuits were here," they effectively strip away the esoteric and often pejorative discussion of the motives and effectiveness of missionary efforts among Native peoples in North America, which has persisted in academic literature for decades. This is a case of using Jesuit documents, or even shadows of such, to reassert sovereignty. The irony is found in the fact that Jesuits actively attempted to convert Native people to Christianity, while subverting their own long-established cultures.

The use of documentary and archaeological evidence in recognition applications is not novel. The Vermont State statute mentions the use of such lines of evidence. ${ }^{71}$ When we review the evidence of seventeenth- and eighteenthcentury associations between Jesuit missionaries and these recognized and applicant Abenaki bands, especially the specific geographic locations of mission sites, there are quite a few lacunae. These bands have employed multiple lines of evidence including oral history, Jesuit documents, secondary historical sources, and archaeological remains, to bind themselves to Jesuits as a vehicle to assert, reify, and defend their identity and claims to tribal homelands. While the legislation does mention the use of archaeology and other lines of

70 Calloway, Western Abenaki, 46-48; and Calloway, Dawnland, 59, among others.

$71 \quad$ Sec. 1.1 VT. Stat. Ann. tit. 9A, § 851. 
evidence, from the manifestation of the legislation through the recognition application process, it is obvious that the European-style written documentation provided by the Jesuits holds a privileged position over all other forms of information available to the applicant bands.

We cannot ignore all the harm missionaries did to the fabric of Abenaki society. Yet, the fact remains that so indelible is the connection between Jesuit history and archaeology and the concept of Native legitimacy, that even the specter of Jesuit missions at Koas and Missisquoi held weight in three cases for state recognition. While Koasek (Cowasuck) Traditional Band of the Sovereign Abenaki Nation failed to gain Vermont State Recognition, the Koasek Traditional Band of the Koas Abenaki Nation and St. Francis/Sokoki Band of the Sovereign Republic of the Abenaki Nation of Missisquoi both succeeded. The tie between archaeology and Native sovereignty strengthens with each use. The case of Vermont State recognition of Abenaki people can be seen as a successful example of applied archaeology and applied Jesuit studies. 